This PDF is a selection from a published volume from the National Bureau of Economic Research

Volume Title: The Changing Frontier: Rethinking Science and Innovation Policy

Volume Author/Editor: Adam B. Jaffe and Benjamin F. Jones, editors

Volume Publisher: University of Chicago Press

Volume ISBNs: 0-226-28672-X, 978-0-226-28672-3

Volume URL: http://www.nber.org/books/jaff13-1

Conference Date: August 2-3, 2013

Publication Date: July 2015

Chapter Title: Innovation and Entrepreneurship in Renewable Energy

Chapter Author(s): Ramana Nanda, Ken Younge, Lee Fleming

Chapter URL: http://www.nber.org/chapters/c13048

Chapter pages in book: (p. $199-232)$ 


\title{
Innovation and Entrepreneurship in Renewable Energy
}

\author{
Ramana Nanda, Ken Younge, and Lee Fleming
}

\subsection{Introduction}

At the time of Vannevar Bush's writing of The Endless Frontier, energy supply was not a major policy concern. To the extent that anyone thought about research related to energy, it was based on the belief that nuclear power would soon be "too cheap to meter." Today, nearly 90 percent of the world's energy is still produced from coal, oil, and natural gas. ${ }^{1}$ We find

Ramana Nanda is associate professor of business administration at Harvard Business School and a faculty research fellow of the National Bureau of Economic Research. Ken Younge is assistant professor in strategic management at the Krannert School of Management at Purdue University. Lee Fleming is professor of industrial engineering and operations research at the University of California, Berkeley.

This chapter was prepared for an NBER conference volume, The Changing Frontier: Rethinking Science and Innovation Policy. We thank the editors of the volume, Adam Jaffe and Ben Jones, and our discussant, Steven Kaplan, for very helpful comments. In addition, we are grateful to Lee Branstetter, Guido Buenstorf, Ronnie Chaterji, Jason Davis, Chuck Eesley, Mazhar Islam, Matt Marx, David Popp, and the participants at the NBER preconference, the Petersen Institute for International Economics, and Stanford Social Science and Technology Seminar for helpful comments. Dan DiPaolo and Guan-Cheng Li provided excellent research assistance. For support we thank the Division of Faculty Research and Funding at Harvard Business School, the Kauffman Foundation's Junior Faculty Fellowship, the Fung Institute for Engineering Leadership at UC Berkeley, and the National Science Foundation (1064182). Parts of this chapter draw extensively on Ghosh and Nanda (2014). For acknowledgments, sources of research support, and disclosure of the authors' material financial relationships, if any, please see http://www.nber.org/chapters/c13048.ack.

1. Data from the BP Statistical Review of World Energy (2012) shows that 87 percent of the energy was produced from "conventional energy," namely coal, oil, and natural gas. On the other hand, solar, wind, biomass, hydro, and other renewables accounted for a mere 8 percent of global energy produced in 2010. The BP study only reports data on commercially traded fuels, including renewable energy that is commercially traded. The International Energy Agency (IEA) estimates a slightly higher share of renewables based on estimates of the use of wood chips, peat, and other biomass used in developing countries that is not commercially traded. Even so, their estimate of renewables including hydroelectricity is 13 percent compared to the 8 percent estimated by BP. 
ourselves with nuclear power facing huge challenges and the development of other noncarbon energy sources a high priority, thus making the role of innovation in renewable energy a first-tier policy concern.

Indeed, the global demand for energy is projected to almost triple over the next several decades. Estimates suggest that a growing world population, combined with rising living standards, will lead global energy consumption to reach about 350,000 terawatt hours (TWh) in 2050 from the 2010 level of $130,000 \mathrm{TWh}$. To put this increase in perspective, it will require the equivalent of setting up 750 large coal-burning power plants per year for forty years in order to meet the increased demand for energy in the coming decades.

In addition to the challenges of meeting the growing energy needs of the world's population with conventional sources of energy, the implications of continued dependence on fossil fuels are believed to be particularly stark for climate change. The shale gas revolution in the United States in recent years has implied a reduced dependence on coal. Nevertheless, the benchmark of trying to achieve "zero emissions" has led the United States and several European countries to focus more intensely on promoting innovation in renewable energy technologies in recent years. While there is no clear winning alternative at present, there is also a growing belief that progress will come from radical innovations that will allow us to make the jump from the status quo, whether it is in renewable energy or other more conventional sources of energy production. In this chapter, we examine the technological and organizational sources of such innovation in renewable energy, with a particular focus on the possible role of venture capitalbacked entrepreneurship.

Ghosh and Nanda $(2014,1)$ point out that "venture capital has been a key source of finance for commercializing radical innovations in the United States, particularly over the last three decades (Kortum and Lerner 2000; Gompers and Lerner 2002; Samila and Sorenson 2011). The emergence of new industries such as semiconductors, biotechnology and the Internet, as well as the introduction of several innovations across a spectrum of sectors such as healthcare, IT and new materials, have been driven in large part by the availability of venture capital for new startups. A key attribute of venture-backed innovation in the US has been the ability of private capital markets to finance a wide variety of approaches in a specific area, as opposed to choosing a specific winner." Since it is hard to know, ex ante, which technological trajectory will be successful ex post, in order to make rapid technological progress, we are likely to need to proceed by conducting numerous "economic experiments" in the energy sector (Rosenberg 1994; Stern 2005; Kerr, Nanda, and Rhodes-Kropf 2014). This makes venture capital (VC) an ideal candidate to play a role in financing radical innovation in renewable energy technologies.

In fact, venture capital financing for renewable energy start-ups rose dramatically in the middle of the first decade of the twenty-first century after 
being consistently low in the previous decades. Between 2006 and 2008, several billion dollars were channeled into start-ups focused on clean technologies, and in particular solar and biofuels-related start-ups. In the last few years, however, venture capital investment in renewable energy technologies has plummeted, falling as a share of overall VC investment and even within clean tech, shifting away from renewable energy production to investments in energy efficiency, software, and storage.

We investigate the role of venture capital in renewable energy innovation by comparing the patenting activity of VC-backed start-ups with other types of organizations engaged in renewable energy innovation. We not only examine patenting rates, but also the characteristics of the patents being filed by the different types of organizations. Understanding these factors will help determine the extent to which falling $\mathrm{VC}$ investment in renewable energy should be seen as a cause for concern as opposed to being easily substitutable by innovation by others such as large incumbent firms.

We address these questions by using patent data from the US Patent and Trademark Office (USPTO) over the thirty-year period from 1980 through 2009. We find that large incumbent firms have dominated patenting in renewable energy for several decades. For example, the top twenty firms accounted for 50 percent of the renewable energy patents and the top fifty firms account for nearly 70 percent of such patents filed at the USPTO in the early 1990s. Innovation became more widespread in the first decade of the twenty-first century when patenting by VC-backed firms grew, but the top twenty firms still accounted for over 40 percent of the patenting activity in 2010. Despite accounting for the largest share of patents, however, we find incumbents are more likely to file patents that are either completely uncited or are self-cited, suggesting a greater focus on incremental or process innovation. Furthermore, they are less likely to have extremely influential patents, that we define as being in the top ten percentiles of forward citations in a given technology area and given year. Finally, we create a measure of novelty using textual analysis of the patent documents that does not depend on citations. This independent measure also suggests that on average, incumbent firms have been engaged in less novel patenting than venture capital-backed start-ups, even more so in the period when VC funding for start-ups increased dramatically. Given the more influential and novel patenting associated with VC-backed start-ups, our results suggest that the sharp fall in financing available for such firms could have implications for the nature of innovation we may see going forward in this sector.

The rest of the chapter is structured as follows. In section 7.2, we outline the data used for our analysis. Section 7.3 provides a detailed description of our main results on the differences in innovation across incumbent and venture capital-backed firms. In section 7.4, we discuss the challenges faced by venture capital investors in sustaining the financing of renewable energy start-ups, and section 7.5 concludes. 


\subsection{Data}

\subsubsection{Sample Selection Criteria}

Our focus in this chapter is on patenting in sectors related to renewable energy production, namely solar, wind, biofuels, hydroelectric power, and geothermal technologies. Before moving to a description of the data, however, we first outline the criteria for selecting our sample.

Our approach was to define a set of technologies that would first, allow us to build a comprehensive and well-delineated data set of patenting activity within the chosen technology, and second, enable us to compare the characteristics of innovation between venture capital-backed start-ups and other firms engaged in innovation.

This led us to leave out some technologies that are often associated with clean energy production, but are not renewable energy. For example, although natural gas has a lower carbon footprint than oil and coal, it is difficult to break out innovations related to energy production in this area, as opposed to other businesses pursued by oil and gas companies. On the other hand, we have also left out other "clean-tech" sectors that receive VC finance but are not energy production. For example, venture capital has been involved in financing a number of innovations in software related to smart grid and energy efficiency. These innovations are extremely difficult to isolate in a systematic manner from other software patents that start-ups could be working on (e.g., a GPS software that helps route trucks in a manner that conserves fuel is hard to distinguish from other GPS patents, even when manually classifying patents). Our focus, therefore, is on renewable energy production technologies that have been patented at the USPTO. ${ }^{2}$ Although our scope is narrower than either "energy production" or "clean tech," our hope is that our trade-off buys us greater confidence in defining a clear and consistent set of technologies within which we can characterize both the trends in patenting over time, and the differences in the nature of patenting across the various organizational forms.

\subsubsection{Data Used to Create the Sample}

We created our sample using three steps. First, we worked with a private research firm, IP Checkups, to define a set of renewable energy patents at the US Patent and Trademark Office (USPTO) in each of the energy production sectors of solar, wind, biofuels, hydro, and geothermal. IP Checkups has particular expertise in clean energy, including a database of clean technology patents filed at the US and foreign patent offices (we consider only patents

2. The focus of our chapter is therefore different and complementary to Popp, Hascic, and Medhi (2011), who look at worldwide patenting of renewable energy technologies. Our emphasis is on organizational differences in the type of patenting with a focus on the USPTO. As we discuss further below, however, our patent sample for the United States seems to correspond well with Popp, Hascic, and Medhi's data on the United States. 
filed with the USPTO). They provided us with a sample of 17,090 renewable energy patents whose application dates were between January 1980 and December 2009 across the five subsectors listed above. ${ }^{3}$

Second, we developed a procedure to validate and extend the sample from IP Checkups in order to ensure that the sample was comprehensive. Specifically, we used the patents from IP Checkups as a training set, and applied the LIBLINEAR machine classifier algorithm (Fan et al. 2008) to search through every patent title and abstract in the universe of approved utility patents at the USPTO with application dates between January 1980 and December 2009. The machine classifier algorithm aimed to identify other patents (based on their titles and abstract) that looked similar to those in the training set provided by IP Checkups. The assumption behind this approach is that IP Checkups may have missed patents at random, but would not have a systematic bias in the types of patents they did not provide us. In this case, the algorithm would be able to search efficiently among the over 4.3 million patents in the universe of patents for others with similar titles and abstracts that may have been overlooked by IP Checkups. The classifier returned an additional 31,712 patents for consideration.

Finally, we contracted with IP Checkups to have a $\mathrm{PhD}$ expert in clean technologies manually review each of the candidate patents identified by the machine classifier and select appropriate ones for inclusion into the final sample. An additional 5,779 patents were selected for inclusion, resulting in a final sample size of 22,869 patents.

We believe that this three-step process outlined above has produced a comprehensive sample of patents looking specifically at renewable energy. Given the systematic and replicable approach used by the machine-learning sample, we believe this method will allow subsequent researchers to easily update the sample, as well as apply similar techniques to identify patents in other sectors that share the property with renewable energy not easily demarcated by specific technology classes at the USPTO. Our approach is therefore complementary to that used by Popp, Hascic, and Medhi (2011), who look at global innovation in renewable energy and also focus on specific patent classes. Although the time period used by our study is somewhat different (our analysis starts in 1980 and extends until 2009), the trends in patenting rates over time are similar. ${ }^{4}$

Having thus identified our five primary categories of clean-tech patents by technology type, we further categorized each patent into one of four organizational types: academia and government, VC-backed start-ups, non-VCbacked firms, and unassigned. Unassigned patents were those with no assignee provided in the patent application. These have typically been assumed to be

3. Although the USPTO data goes as far as 2012, we truncate the sample at the end of 2009 to allow for our analysis of forward citations.

4. Our data set contains a larger number of patents than the Popp, Hascic, and Medhi (2011) database does for the United States. This is likely due to the fact that our search procedure extended beyond the primary set of patent classes used by these technologies. 
independent inventors, but may also be corporate patents with just a missing assignee field. As we show in the following section, unassigned patents seem significantly different in terms of their characteristics. While we do report some analyses that include unassigned patents, the majority of our analyses focus on comparisons between VC-backed start-ups, non-VC-backed firms, and inventors in academic institutions or government labs. We classified firms as venture-capital backed if the assignee name and location corresponded with firms in either the Cleantech 33 or the Bloomberg New Energy Finance database of venture capital-backed financings. ${ }^{5}$ To classify assignees as university or government, we used a text-matching process followed by manual review to identify academic institutions (assignees with words such as "university," "universitaet," "ecole," "regents," etc.) and governmental organizations (assignees with words such as "Department of Energy," "United States Army," "Lawrence Livermore," "Bundesrepublik," etc.).

Our residual category, therefore, is the category of assignees that are not $\mathrm{VC}$ backed and not from academic institutions or the government. The residual category can therefore be thought of as incumbent firms (keeping in mind the qualifications described above). As far as possible, we manually matched subsidiaries to the parent company's name, so that, for example, all known subsidiaries of General Electric were classified as GE. While this categorization is imperfect, cases where we missed matching a subsidiary to a parent company will tend to bias us toward finding less concentration in patenting, and our findings should be seen as a lower bound to the true level of concentration across organizations involved in renewable energy patenting.

\subsection{Results}

\subsubsection{Patenting Rates in Renewable Energy}

We begin by providing an overview of the patenting landscape in renewable energy technologies. Figures 7.1A and 7.1B report the absolute and relative amount of renewable energy patenting at the USPTO, broken down by technology. They show that renewable energy patents fell over the 1980s, both in absolute and relative terms. While the patenting rate increased slightly in the 1990s, it rose considerably in the first decade of the twenty-first century, increasing at a disproportionate rate relative to overall patenting activity at the USPTO. In fact, both the number of patents filed per year and the share of patents filed in the USPTO approximately doubled over the ten-year period from 2000-2009. They also show that the increase was due to solar, biofuels, and wind patenting in particular, while hydro and geothermal patents

5. Both databases have more comprehensive coverage of venture capital financings in clean energy than Thompson Venture Economics and Dow Jones Venture Source, the two databases typically used for studies on venture capital-backed start-ups. 


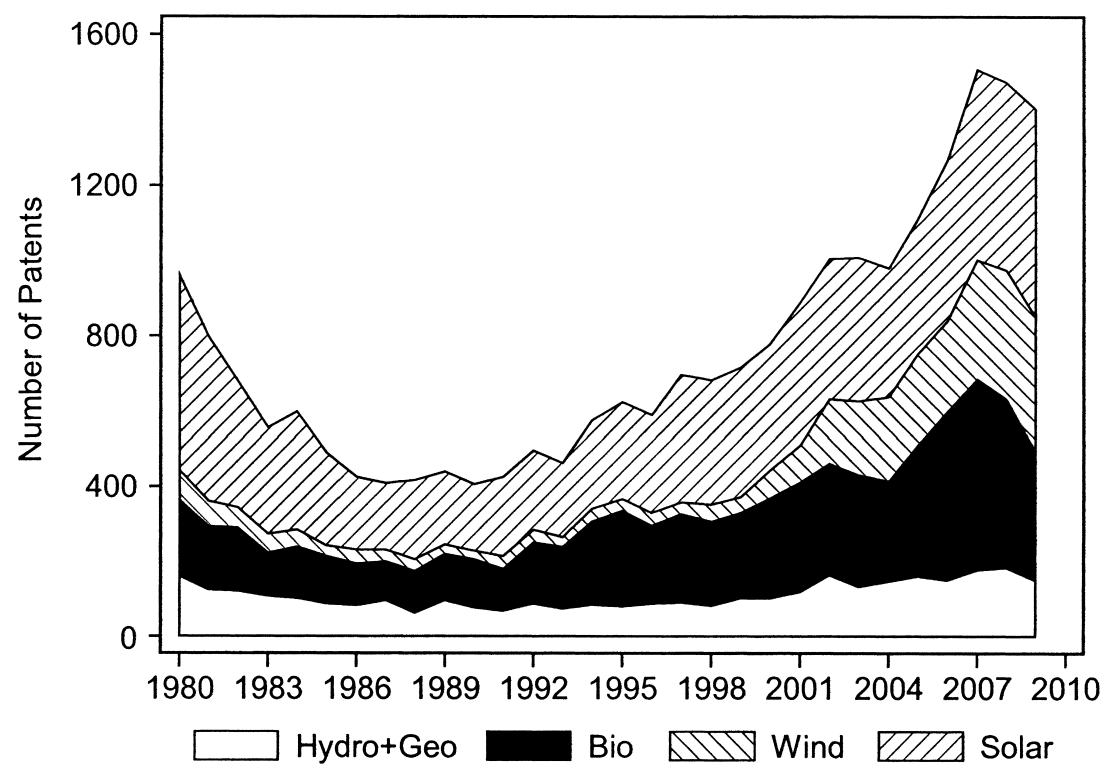

Fig. 7.1A Count of renewable energy patents at USPTO by technology, 1980-2009

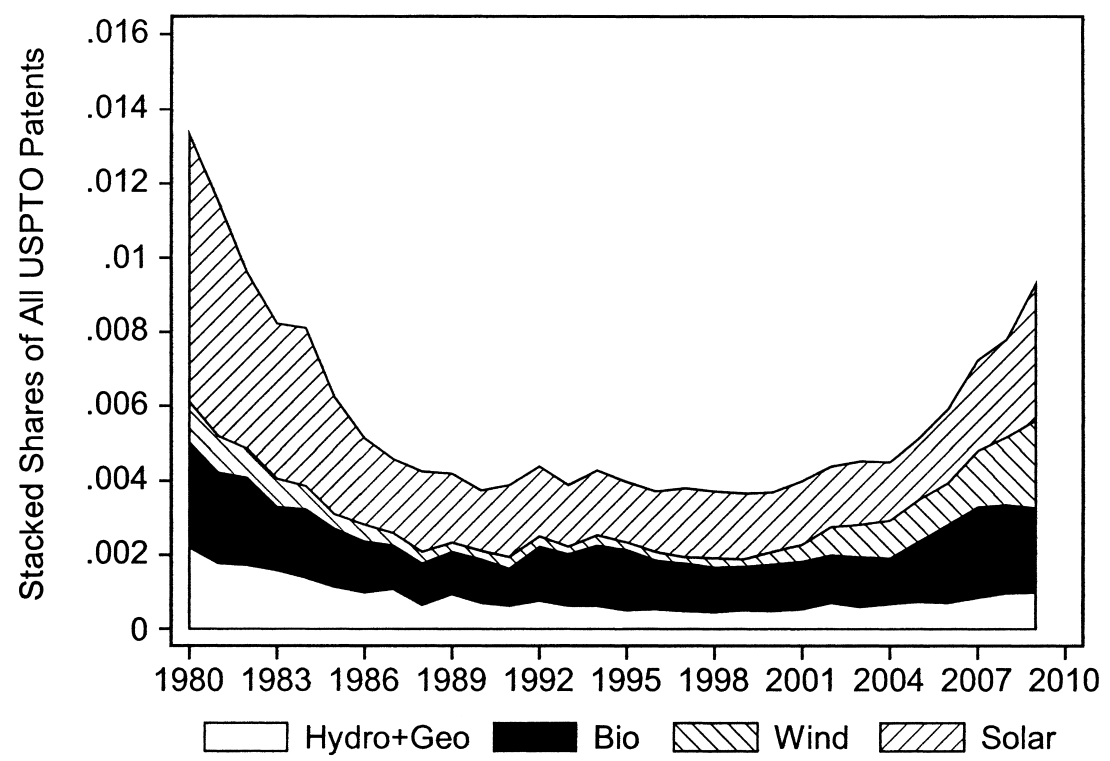

Fig. 7.1B Share of renewable energy patents at USPTO by technology, 1980-2009 


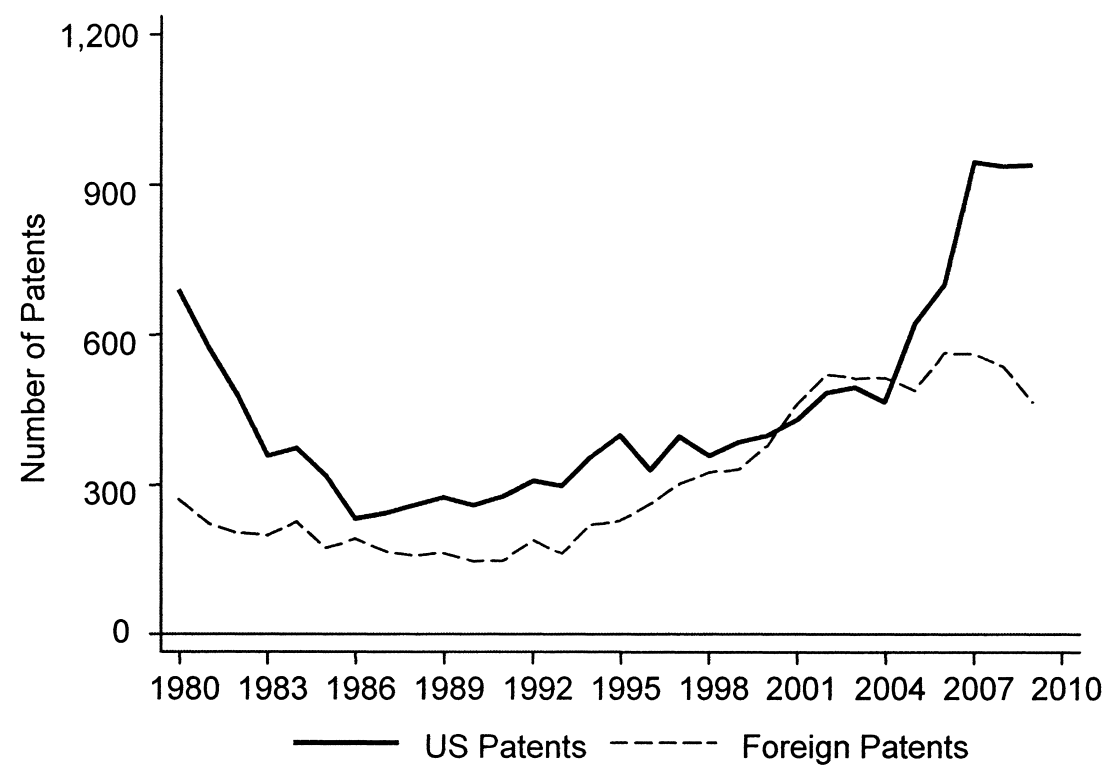

Fig. 7.2 USPTO patents granted to foreign and US-based inventors, 1980-2009

remained about constant over the period. Figure 7.2 shows that the increase in patenting was much greater among US-based inventors than those based outside the United States. In fact, there was a sharp break in the trend of patenting by US-based investors relative to foreign inventors around 2004.

Tables 7.1A and 7.1B provide a breakdown of the total number of patents used in our sample, broken down by organizational form and technology area. Table 7.1A reports the breakdown for the entire sample, while table $7.1 \mathrm{~B}$ reports the results for inventors who are based in the United States. ${ }^{6}$ Solar and biofuels are the two largest categories and account for about 75 percent of the patents in our sample. Incumbent firms account for nearly two-thirds of the patents in the data set and about 55 percent of the patents filed by US-based inventors.

Table 7.2 provides more detail by listing the most active US-based assignees patenting in renewable energy in recent years and the number of patents

6. Since our sample looks only at patents at the USPTO, "foreign inventors" are those who live outside the United States and have chosen to patent their inventions in the United States. Of course, there are likely to be significant numbers of renewable energy inventions by foreign inventors that are not patented at the USPTO. For example, a number of patents related to solar in Germany are not patented in the United States. However, given that the United States is such an important market, our prior is that important patents would in fact be patented in the United States in addition to other countries. Anecdotal evidence suggests that this is indeed the case. Nevertheless, the structure of our sample does not allow us to make substantive conclusions about US versus foreign patents, or speak to differing trends in patenting between US and foreign inventors in renewable energy over time. 
Patenting rates in renewable energy, by technology and organization type

\begin{tabular}{|c|c|c|c|c|c|c|}
\hline & $\begin{array}{l}\text { Venture- } \\
\text { backed } \\
\text { start-ups }\end{array}$ & $\begin{array}{l}\text { Incumbent } \\
\text { firms }\end{array}$ & $\begin{array}{l}\text { Academia } \\
\text { and } \\
\text { government }\end{array}$ & Unassigned & Total & Percent \\
\hline \multicolumn{7}{|c|}{ A. All renewable energy patents at USPTO (1980-2009) } \\
\hline Solar & 473 & 5,937 & 732 & 2,502 & 9,644 & 42 \\
\hline Wind & 169 & 1,679 & 70 & 1,129 & 3,047 & 13 \\
\hline Biofuels & 177 & 4,995 & 884 & 778 & 6,834 & 30 \\
\hline Hydroelectric & 78 & 1,132 & 107 & 1,058 & 2,375 & 10 \\
\hline Geothermal & 52 & 597 & 54 & 266 & 969 & 4 \\
\hline Total & 949 & 14,340 & 1,847 & 5,733 & 22,869 & 100 \\
\hline \multicolumn{7}{|c|}{ B. US-based inventors only } \\
\hline Solar & 402 & 2,797 & 482 & 1,884 & 5,565 & 41 \\
\hline Wind & 71 & 689 & 39 & 693 & 1,492 & 11 \\
\hline Biofuels & 143 & 2,987 & 659 & 513 & 4,302 & 32 \\
\hline Hydroelectric & 41 & 643 & 68 & 757 & 1,509 & 11 \\
\hline Geothermal & 29 & 431 & 42 & 219 & 721 & 5 \\
\hline Total & 686 & 7,547 & 1,290 & 4,066 & 13,589 & 100 \\
\hline
\end{tabular}

Notes: This table reports the breakdown of 22,869 renewable energy patents at the USPTO that were granted between 1980 and 2009. Panel A provides a breakdown for the entire sample and panel B provides a breakdown for US-based inventors. Venture-backed start-ups refer to patents where the assignee was matched to a firm that received venture capital finance (identified using data from Cleantech i3 and Bloomberg New Energy Finance). Patents granted to academic institutions or government labs were identified using a text-matching algorithm followed by manual review. Incumbent firms refer to the residual category of assignees who were not classified as either VC-backed or from academia/government. Unassigned patents are those not affiliated with any organization and are typically seen as independent inventors.

associated with these. Specifically, it focuses on the assignees with at least five patents between 2005 and 2009 in each of the technologies. As can be seen from table 7.2, large energy and energy-equipment incumbents account for the disproportionate share of the overall patenting. Firms such as GE, DuPont, Chevron, ExxonMobil, and Applied Materials are among the most active firms patenting in renewable energy. However, a number of VCbacked firms are also on this list. For example, SoloPower, Konarka Technologies, Stion, Nanosolar, Solyndra, MiaSolé, Twin Creeks Technologies, and Solaria are all VC-backed firms, so that eight of the top twenty assignees with US-based inventors patenting in solar between 2005 and 2009 were VC-backed start-ups. Similarly, Amyris, KiOR, and Ceres in biofuels; Clipper Windpower and FloDesign Wind Turbines in wind; and Ocean Power Technologies and Verdant Power in hydro are all venture capital-backed firms. ${ }^{7}$

7. Appendix A provides a more detailed list of the top assignees from VC-backed start-ups, incumbents, and academia/government, including both US and foreign inventors patenting at the USPTO and over the period 2000-2009. Given that the list includes assignees with many foreign inventors, other familiar names such as Vestas, Sanyo, Sharp, Gamesa, and Schott AG are now also among the leading assignees involved in renewable energy innovation. 


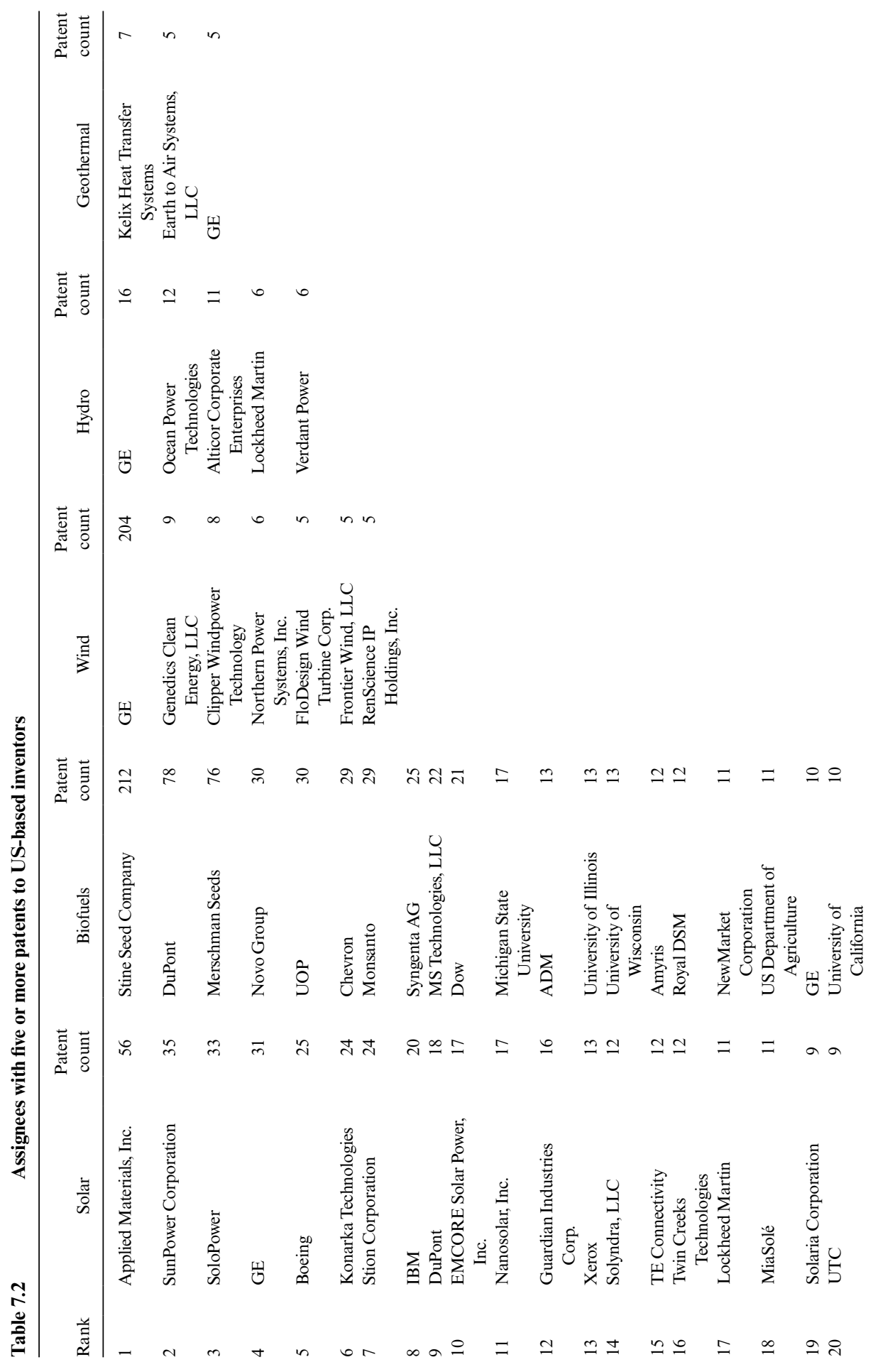


a $\infty \times 6$ o 0 in in in in in in in

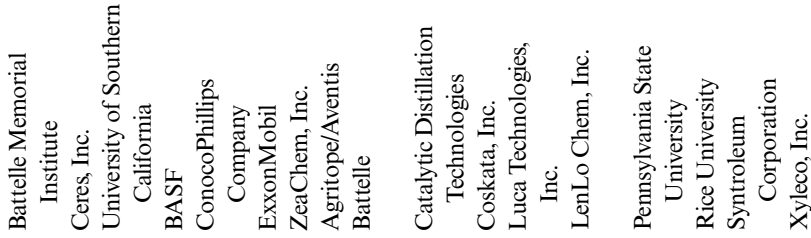

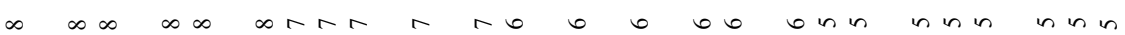

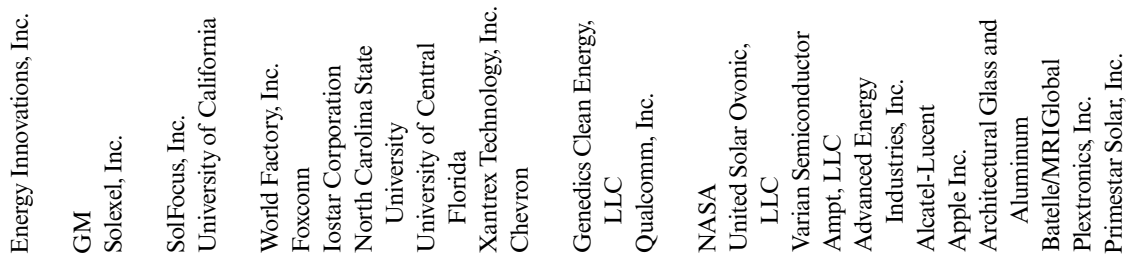

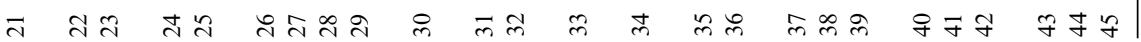


Figure 7.3 helps address the apparent discrepancy that stems from comparing table 7.1 (where VC-backed start-ups have a small share of patents over the entire period) to table 7.2 (where VC-backed start-ups are prominent in the last five years). It shows how VC-backed start-ups increased their proportional share of patenting by US inventors the most over this period, increasing the share of patenting from under 5 percent in 2000 to almost 20 percent of the patents filed in 2009. Table 7.2 and figure 7.3 highlight how VC-backed start-ups have grown to become much more important contributors to innovation in renewable energy in the last few years.

Despite the sharp increase in patenting by VC-backed start-ups, however, patenting in renewable energy still remains concentrated in a relatively small number of firms. Figure 7.4 documents the share of total patents filed by US inventors working at either incumbents or venture capital-backed firms that are attributed to the ten, twenty, and fifty most actively patenting firms in each year. As can be seen in figure 7.4, the top twenty firms accounted for about half of all the renewable energy patents filed by firms in the early late 1980s and early 1990s. Although the concentration has fallen from that peak, it is still over 40 percent in 2009.

\subsubsection{Characteristics of Patenting by Incumbent versus VC-Backed Firms}

We next compare the characteristics of the patents filed by the different types of organizations. Our first step is to examine the citations to the patents that they file. Since citations tend to have a highly skewed distribution, we report the results from count models. Table 7.3 reports the results from negative binomial regressions, where the dependent variable is the count of citations received for each patent. Although we include technology and year fixed effects to account for fixed differences in patenting propensities across technologies and to account for cohort differences in the number of citations, we nevertheless also account for the fact that patents in 1980 would have received more citations than those in 1995 by looking at the cumulative citations received by patents five years from the year of application. Our measure of citations excludes selfcitations, so we examine the influence of the patents on other assignees.

Panel A of table 7.3 reports results on both US and foreign inventors, while panel B restricts the sample to US-based inventors. Columns (1), (2), and (3) of both panels report the results for all technologies together, while columns (4), (5), and (6) split out the three most prevalent technologies - solar, biofuels, and wind. We use academic and government patents as our reference group, as they are likely to have remained the most stable over the entire period.

Table 7.3 shows some interesting patterns. First, as noted above and consistent with prior findings (Singh and Fleming 2010), unassigned patents seem to be far less influential than patents with assignees, both in the full sample and for US-based inventors. When interpreted as incidence rate ratios, panel A, column (1) implies that unassigned patents are associated with a 75 percent lower citation rate than academic and government patents. Second, patents 


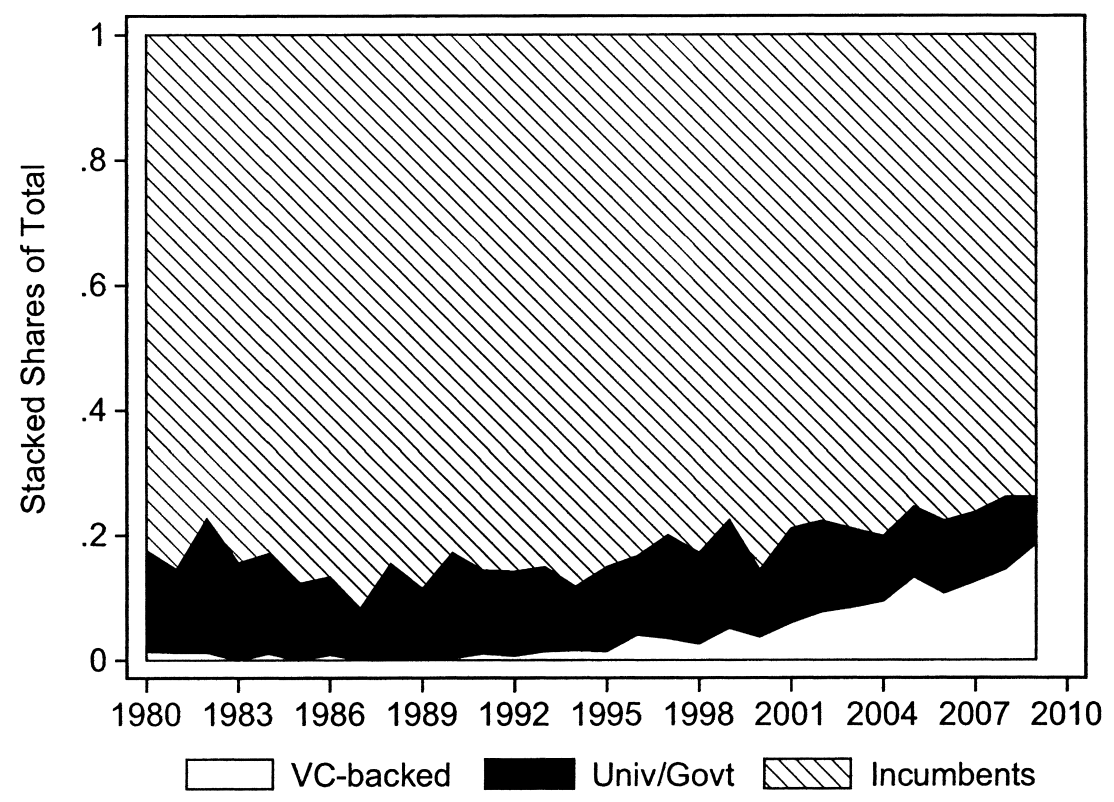

Fig. 7.3 US assignees of renewable energy patents by organization type, 1980-2009

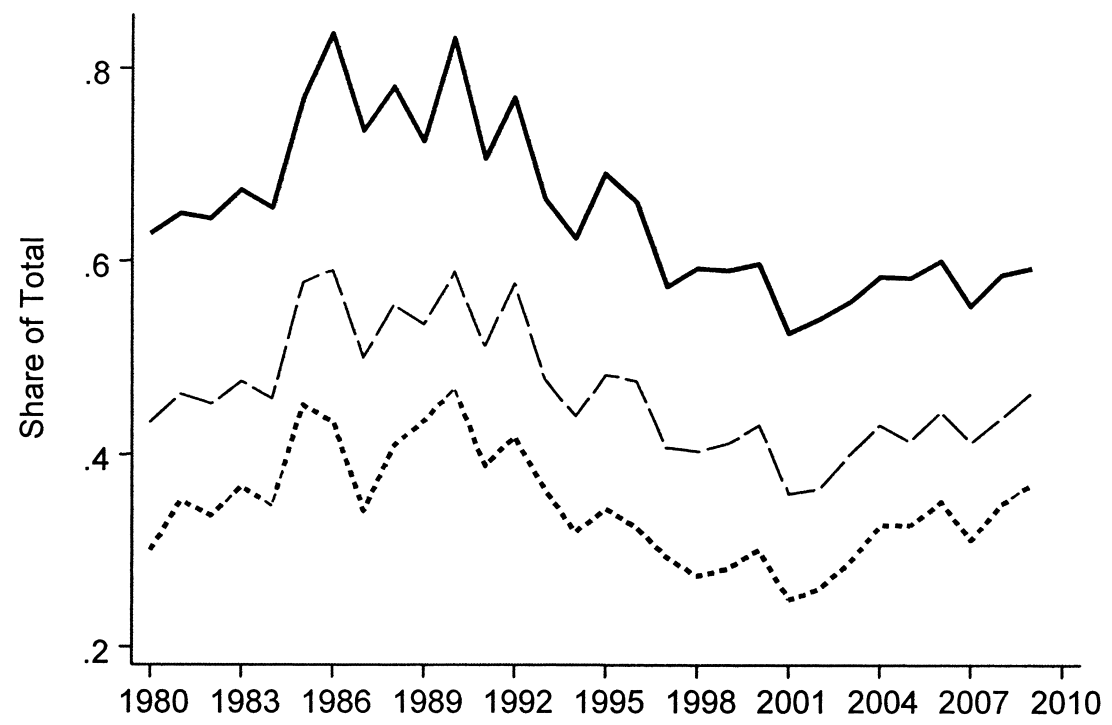
Top 50 Firms - - Top 20 Firms ........ Top 10 Firms

Fig. 7.4 Concentration of renewable energy patenting, US assignees, 1980-2009 


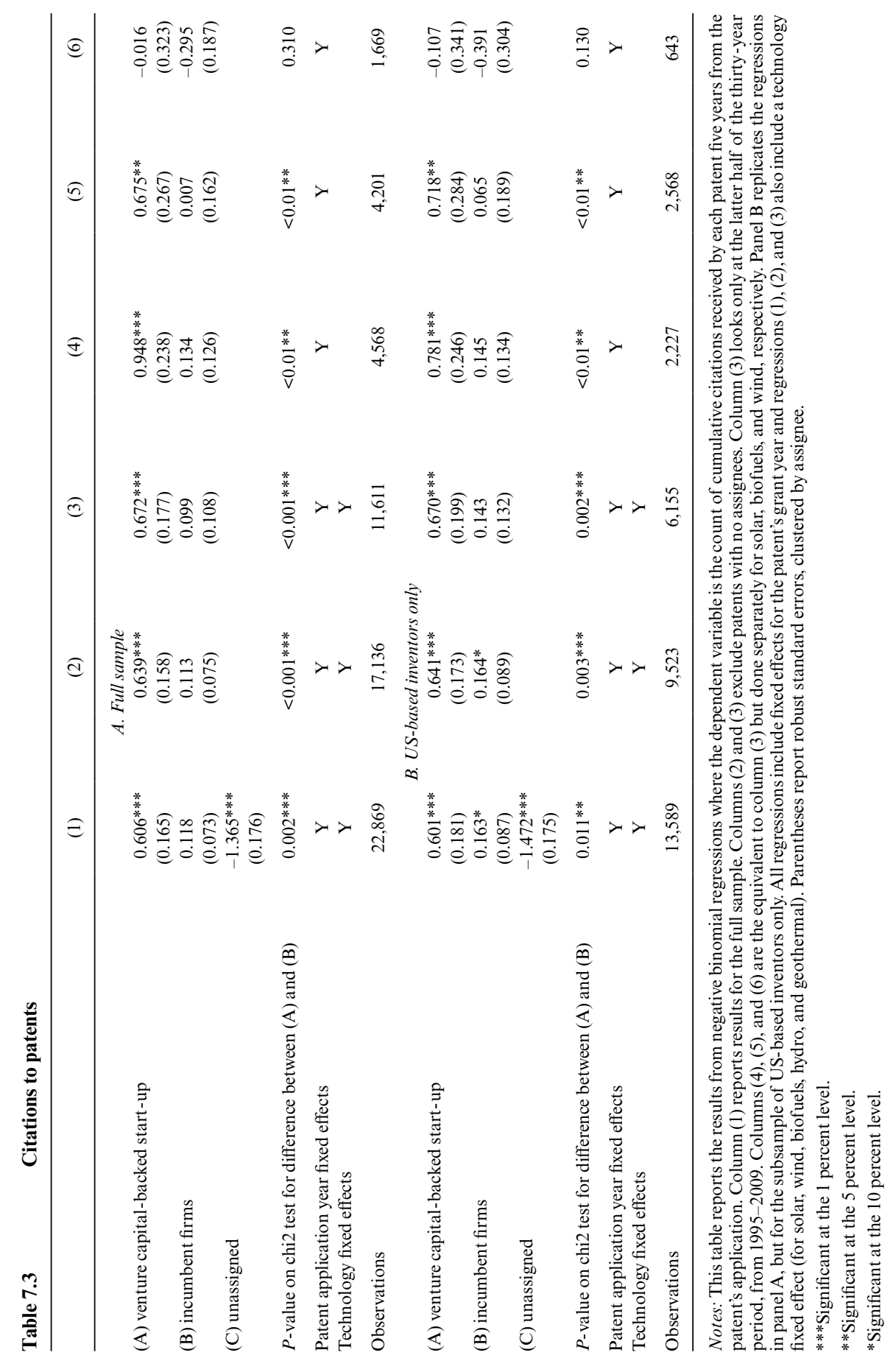


filed by incumbent firms are slightly more influential than academic patents, but only marginally so. The economic magnitude is small and it is imprecisely estimated. Incumbents are associated with a citation rate that is 1.1 times that of university and government patents. On the other hand, patents filed by VC-backed firms are much more likely to receive subsequent citations. The economic magnitudes are large. The coefficients imply that VC-backed start-ups are associated with a citation rate that is 1.9 times that of university and government patents. In addition, a chi2 test for the difference in the coefficient between citations to VC-backed firms and incumbents shows that the differences are statistically significant. Columns (4), (5), and (6) explore the extent to which these differences come from certain technologies versus others. They highlight that the differences we see in columns (1), (2), and (3) are strongest for solar and biofuels - the two technologies that account for 75 percent of the overall patents in our data. Venture capital-backed start-ups patenting in wind technologies receive more citations than incumbents, but these differences are not statistically significant in panel A and only close to marginal significance in panel B. ${ }^{8}$ This seems consistent with the fact that the largest amount of venture capital finance was devoted to solar and biofuels (a fact discussed in great detail in section 7.4).

The difference in the overall level of citations between VC-backed startups and incumbent firms could come from two different fronts. First, it is possible that VC-backed firms have fewer marginal or uncited patents, so that the difference stems from the left tail of the citation distribution being better. Second, it is possible that VC-backed firms are more likely to have highly cited patents, so that even if the left tail of the distribution is no better, the intensive margin of citations is higher, including a thicker right tail. To probe these possible explanations, we examine both the share of patents with at least one citation and the share of patents that are highly cited.

Table 7.4 reports the results from ordinary least squares (OLS) regressions where the dependent variable takes a value of one if the patent received at least one citation. Again, unassigned patents are far less likely to receive a single citation. The coefficients imply a 35-38 percentage point lower chance of being cited relative to academic patents on a baseline of a 50 percent citation probability. Both VC-backed start-ups and incumbents have patents that are more likely to receive citations than patents by inventors in university and government labs. This, of course, could be due to the basic nature of academic and government research and development (R\&D). When comparing VCs and incumbents, however, we find that VCs have an 11-14 percentage point higher likelihood of being cited relative to academic labs, compared to a 5-7 percentage point higher probability for incumbents. These differences are statistically significant, suggesting that on average,

8. While we do not separately report the effects by technology in subsequent tables, we find exactly this pattern for the other measures that we examine in tables 7.4-7.7. 


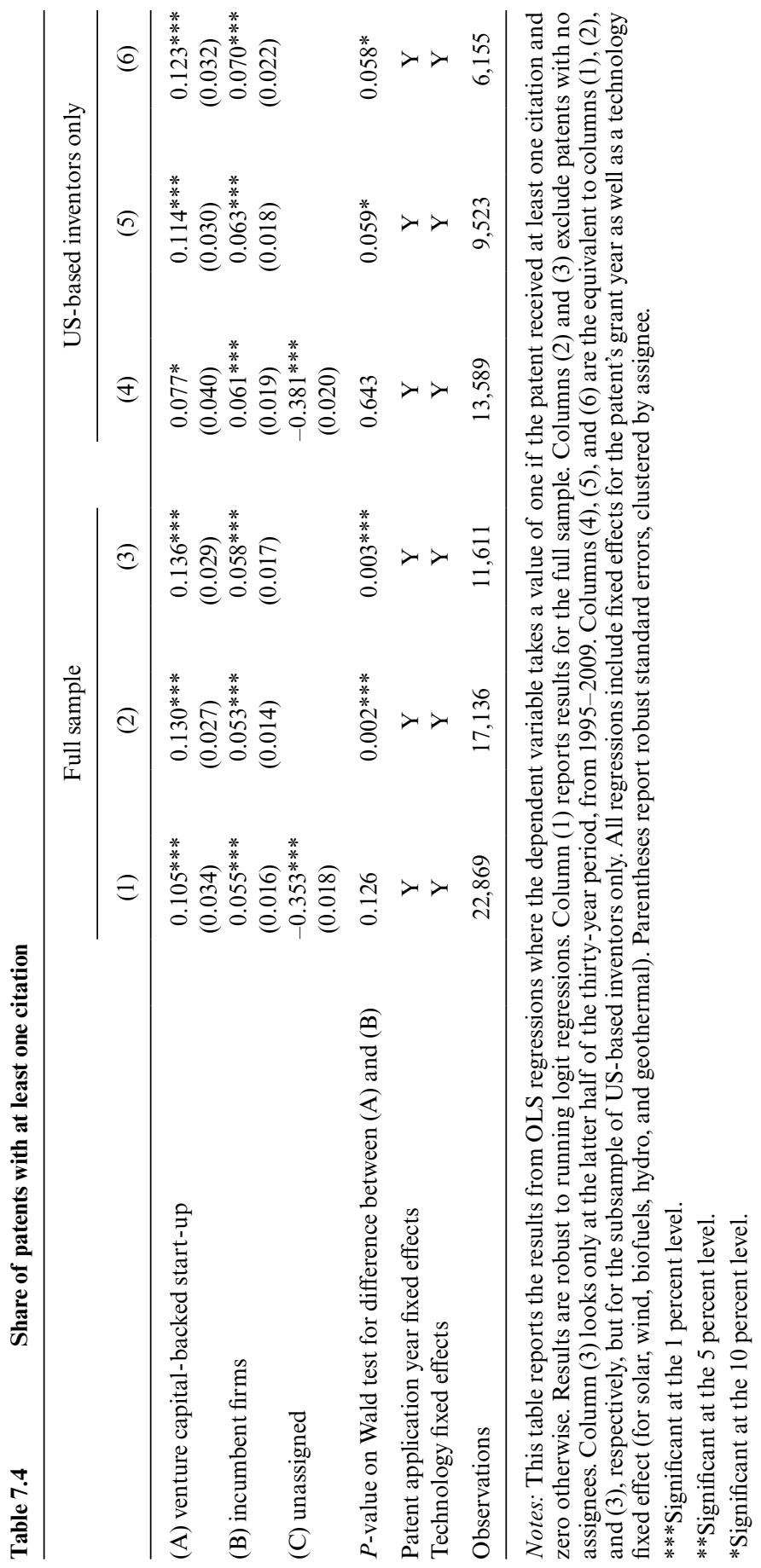


VC-backed patents are less likely to be marginal and more likely to influence future R\&D.

Table 7.5 reports the results from OLS regressions where the dependent variable is equal to one if the patent was highly cited. Specifically, we define a patent as being highly cited if the citations for that patent are in the top 10 percent of five-year forward citations for patents in that technology and year. Table 7.5 shows that unassigned patents are much less likely to have a highly cited patent. Since the baseline probability is by definition about 10 percent, the coefficients on unassigned patents in columns (1) and (4) of table 7.5 point out that the chance of such a patent being highly influential is essentially zero. On the other hand, VC-backed firms are almost twice as likely as academic patents to be highly cited. Incumbent firms have no statistically significant difference in highly cited patents in the overall sample, and a slightly higher chance among US-based inventors. However, importantly, the difference in the chance of being highly cited between VC-backed firms and incumbents is both statistically and economically significant.

Thus far our analysis has suggested that renewable energy innovation by incumbent firms tends to be less influential. Innovation by incumbents is less likely to be cited at all and when it is, it is less likely to be highly cited. These results are consistent with the literature that has documented that incumbent firms have different goals, search processes, competencies, and opportunity costs that lead them toward more incremental innovation (Tushman and Anderson 1986; Henderson and Clark 1990; Tripsas and Gavetti 2000; Rosenkopf and Nerkar 2001; Akcigit and Kerr 2011), although these papers have not directly compared innovation by incumbents with that by VC-backed start-ups.

To probe our results further, we turn next to directly examine the extent to which incumbents pursue more incremental innovation, by examining the degree to which they cite their own prior work relative to other types of organizations. Following Sorensen and Stuart (2000), we hypothesize that if firms are citing their own patents at a disproportionate rate, then they may be engaged in more "exploitation" rather than "exploration" (March 1991). We therefore study the extent to which inventors in the different organizational settings tend to cite themselves.

Table 7.6 reports the results from negative binomial regressions where the dependent variable is the count of the self-citations a focal patent makes, where a self-citation is defined as citing a patent from the same assignee. The regressions control for the total number of citations the patent made, and technology and patent application year fixed effects. As can be seen from table 7.6, VC-backed firms are no more likely to cite themselves than academic labs. Although the coefficient is in fact negative, it is imprecisely estimated. On the other hand, the coefficient on incumbent firms implies that they are 50 percent more likely to cite themselves compared to academic labs. Again, the difference between VC-backed firms and incumbents is statistically significant, suggesting that part of the reason that incumbents have less 


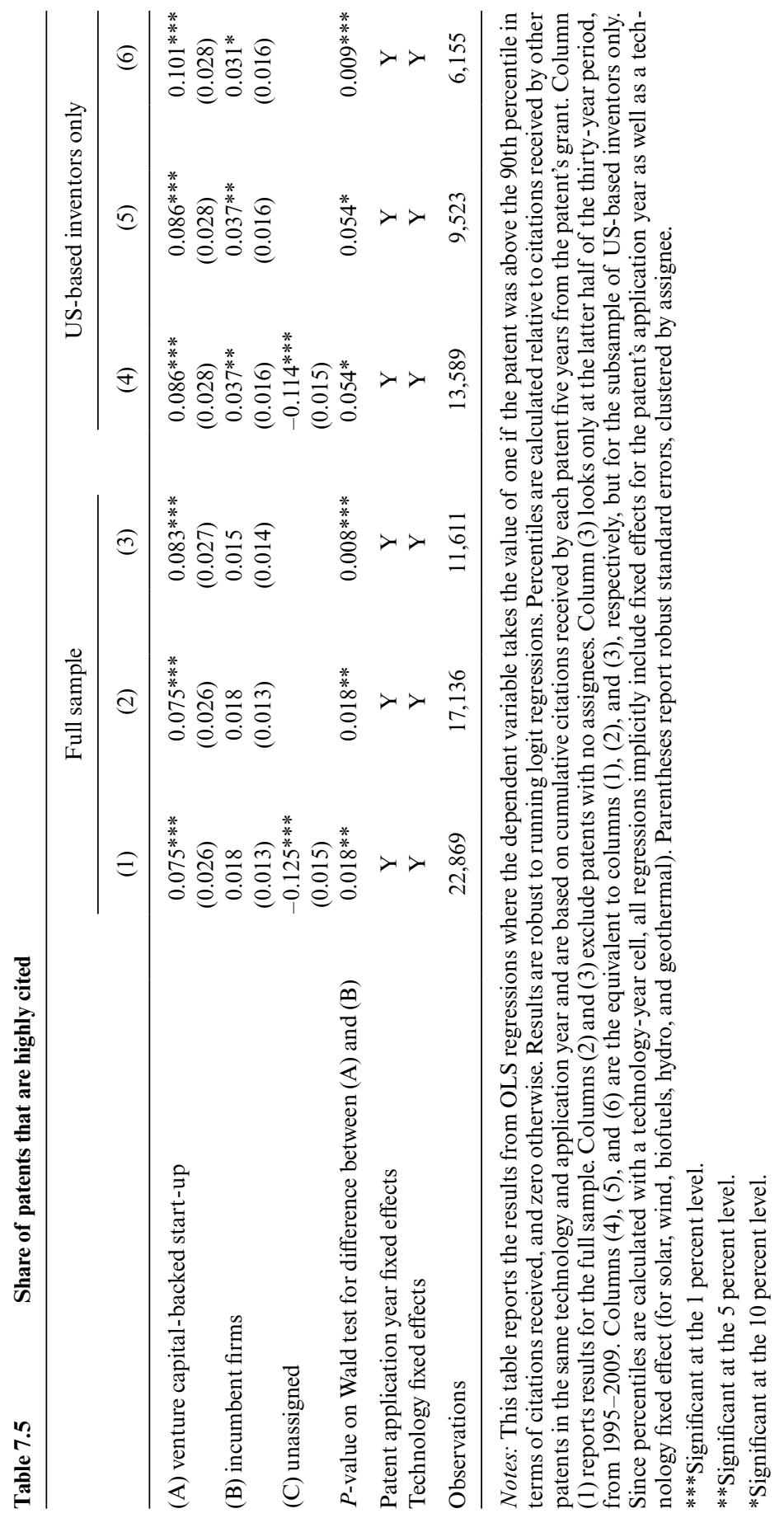




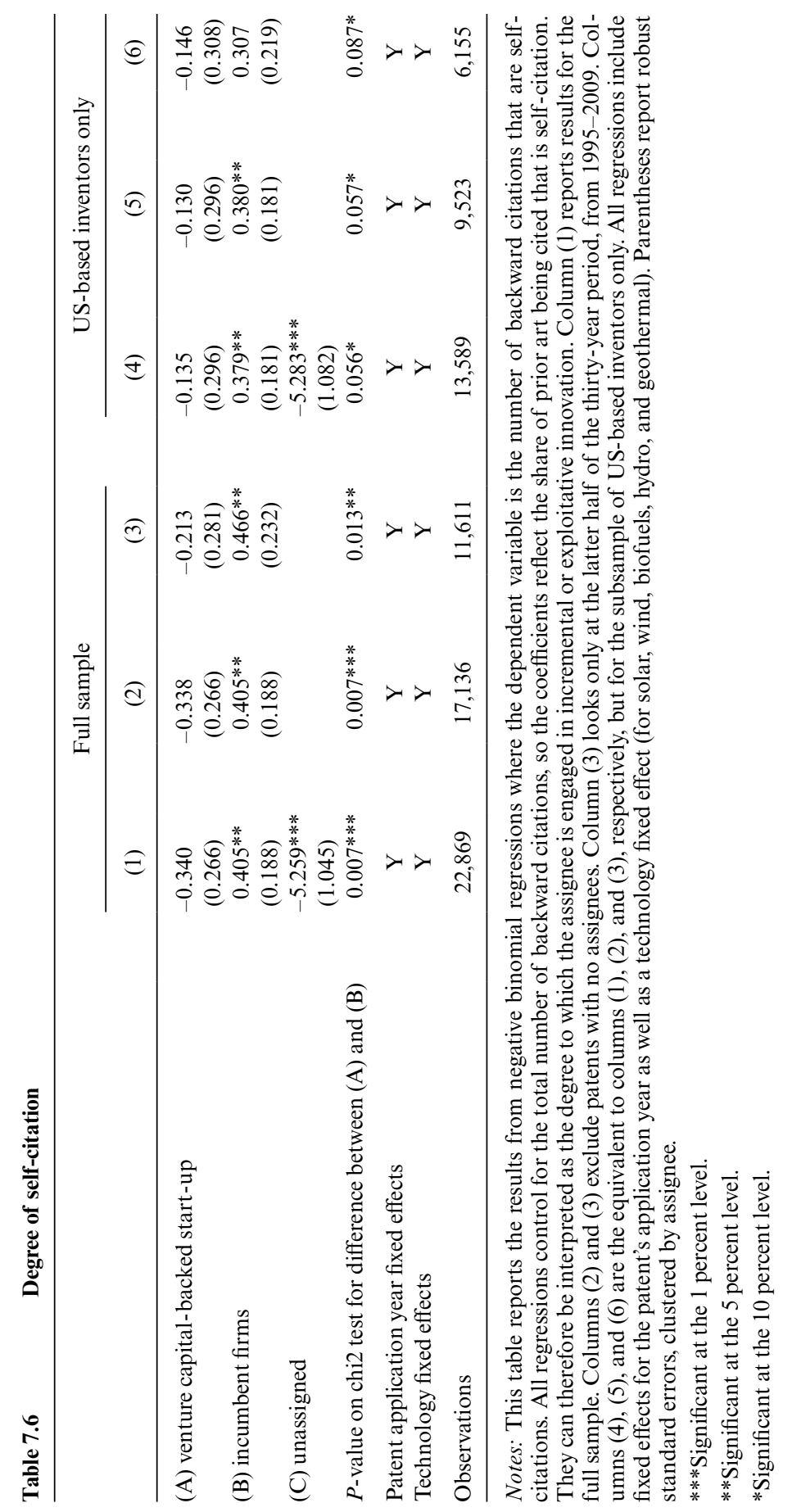


influential innovations is that they are engaged in more incremental $R \& D$ than VC-backed start-ups.

One possible reason for not being cited at all and for citing one's own work could also be that firms are engaged in extremely novel innovations that have not yet yielded citations. This could be particularly true in nascent technologies such as renewable energy. In addition, since patenting activity is concentrated in a few incumbent firms, it is possible that some of the higher self-citation is purely due to the fact that the prior art to be cited is more likely to be that of incumbents or that VC-backed firms do not have many prior patents to cite.

In order to address these concerns, we use a new measure of novelty that is not based on citation measure. Instead, we draw on a textual analysis of patent applications to look at the similarity of patent claims and descriptions for patents in a given technology area. Intuitively, our definition is such that patents with greater textual similarity to neighboring patents are considered to be less novel. Our measure of novelty should be particularly useful in the context of science-based patenting, where technical terms are more unique and therefore more likely to signal differences in the characteristics of innovation, and for more recent time periods, where initial forward citations may be a noisy predictor of ultimate outcomes. The measure also avoids problems with citation-based measures, where citation patterns can suffer from selection biases. A more detailed description of the measure is outlined in appendix B (see also Ullman and Rajaraman 2011, 92-93).

As can be seen from table 7.7, our novelty measure is quite consistent with the other citation-based measures of patenting. First, it highlights that in addition to unassigned patents not receiving many citations, they are also less novel than patents being developed in academic and government labs. The regressions highlight that the novelty of the patents for VC-backed start-ups is no different from that of academic labs. However, incumbent firms have a significantly lower level of novelty. Although the difference between the novelty of patenting by incumbent and VC-backed firms is not significant for the overall sample, it is close to being significant at the 10 percent level for US-based inventors, particularly in the latter part of our sample.

Our results therefore suggest that incumbent firms have been engaged in less novel and exploratory innovation than VCs, in particular in the United States. However, it is also important to weigh these differences in the quality of innovation against the patenting rates discussed before. First, as shown in table 7.1 and figure 7.3, the vast majority of the patents in renewable energy still come from incumbent firms. Despite the fact that a larger share of these are completely uncited and are less likely to be influential, incumbents still account for the largest share of innovation in aggregate. Second, it is important to remember that process improvements and innovations may be particularly important in the energy sector, where large-scale implementation can help reduce cost and make new technologies more competitive and get closer to "grid parity." 


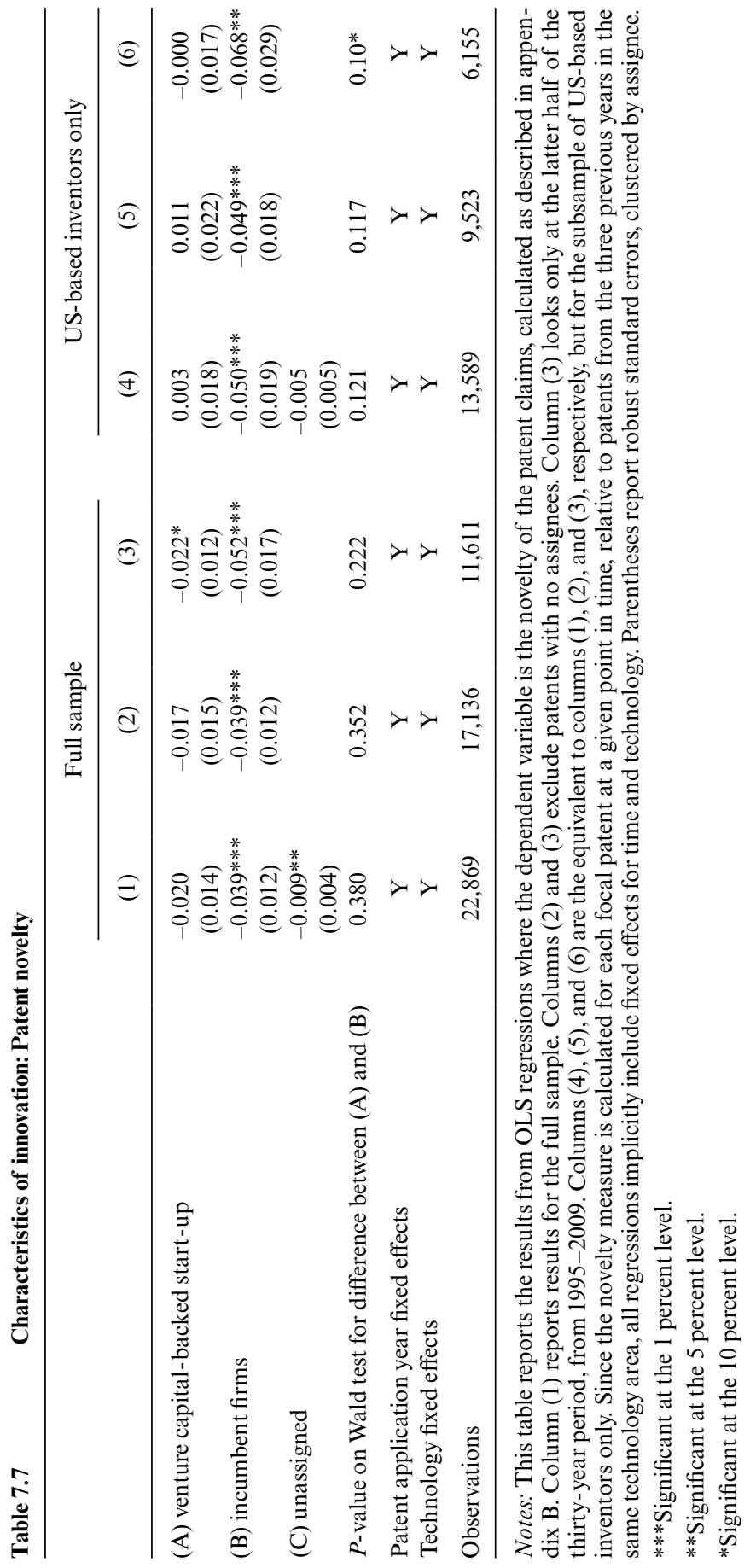




\subsection{Venture Capital Financing of Renewable Energy Start-Ups ${ }^{9}$}

Thus far we have documented that VC-backed start-ups have increased their share of patenting most substantially over the past decade and that these start-ups seem to be associated with more radical and novel innovation than that by incumbent firms. We next document that the timing of growth in renewable energy patenting by VC-backed firms is closely associated with venture capital dollars flowing into renewable energy startups. In 2002, only forty-three clean energy start-ups received VC funding in the United States, raising a combined total of $\$ 230$ million. In 2008, over 200 clean energy start-ups raised $\$ 4.1$ billion in venture capital in the United States. ${ }^{10}$ Figure $7.5 \mathrm{~A}$ shows points to the fact that VC investment in renewable energy was greatest in solar and biofuels. Figure 7.5B shows that investment in renewable energy almost doubled as a proportion of first financings. When taking later-stage investments into account, the effects are even more pronounced-clean energy investments accounted for about 15 percent of the total dollars invested by VCs in the United States in 2008, of which a majority went to renewable energy technologies. Figures 7.5A, 7.5B, and 7.5C also show that in the last few years venture capital investment in renewable energy technologies has fallen sharply, in absolute terms, as a share of overall VC investment and even within clean tech, shifting away from renewable energy production technologies.

Although our work cannot distinguish whether VCs lead start-ups to engage in more radical innovation or are just able to select more radical innovations than the incumbents tend to fund, it does highlight that venture capital financing seems to be associated with more novel and high impact innovation in renewable energy, particularly late in the first decade of the twenty-first century (Conti, Thursby, and Thursby 2012). ${ }^{11}$ This seems important given the need for the widespread experimentation required to make progress in providing low cost, clean energy that will support development without incurring massive costs in terms of climate change. To the extent that the shift in venture capital finance away from such technologies is due to structural factors, it suggests that this will have a noticeable impact on the type of innovation being undertaken in renewable energy. ${ }^{12}$

9. This section draws extensively on Ghosh and Nanda (2014), which goes into greater detail on the financing model of venture capital and why it is poorly suited to financing renewable energy start-ups.

10. Source: Ernst and Young, National Venture Capital Association Press Releases, as reported in Ghosh and Nanda (2014).

11. Note that simply looking at the timing of the patents and the investment will not help untangle the causality as VCs will often invest in firms that have promising technologies in the anticipation that they will patent.

12. We should note that this could be equally true either through the treatment or the selection effect of venture capital investment. Even if venture capital was associated with the greater level of innovation due to its role in "picking radical technologies" rather than leading firms to become more innovative, a lack of willingness to finance renewable energy technologies could still impact innovation and commercialization in this sector as it would lead promising technologies to go unfunded. 


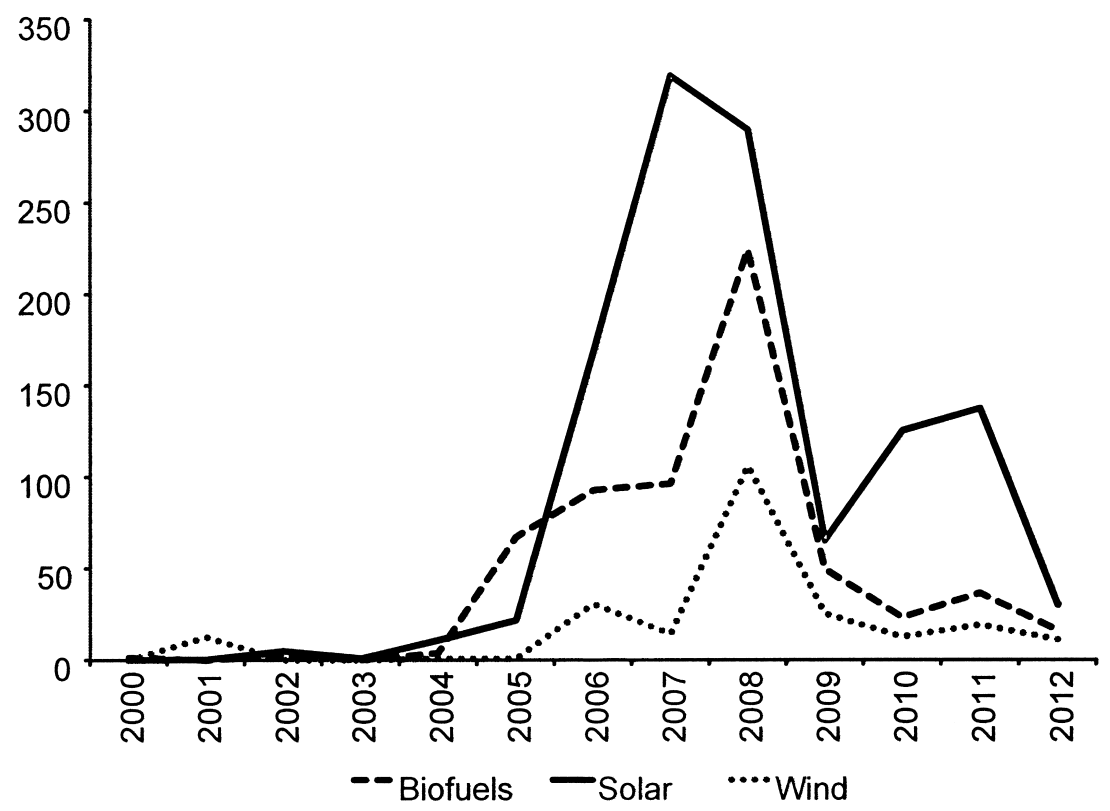

Fig. 7.5A Series A financing for US-based start-ups in solar, wind, and biofuels, by sector (United States only, millions of dollars)

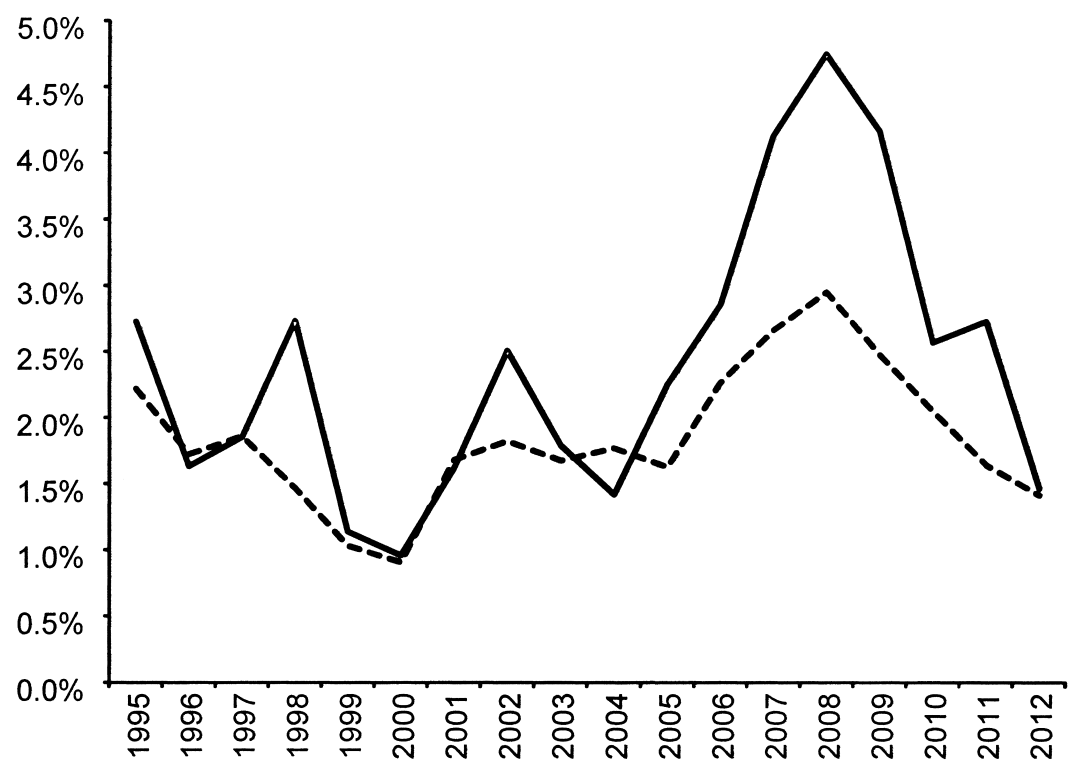

-- Industrial / Energy share of deals - Industrial / Energy share of total dollars

Fig. 7.5B Industrial/energy share of total VC investments (first-series financings only) 


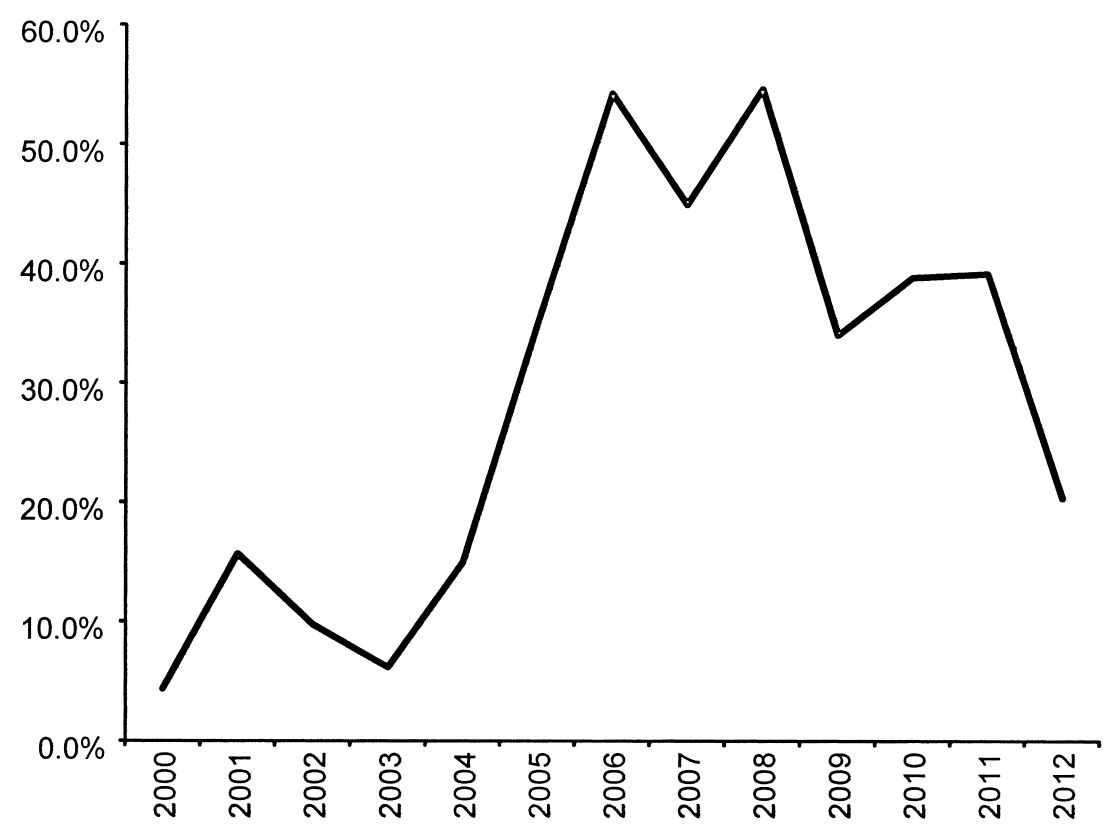

Fig. 7.5C Share of series A clean-tech financings by VCs going to solar, wind, and biofuels start-ups

Needless to say, a number of factors are likely responsible for the rapid decline in VC financing for renewable energy start-ups. The economic collapse in 2009 had a chilling effect on all venture capital investment, including clean energy. In addition, improvements in hydrofracking technology that opened up large reserves of natural gas lowered the cost of natural gas considerably and changed the economics of renewable energy technologies in terms of them being close to "grid parity." Nevertheless, our discussions with venture capital investors suggest that there are in fact structural factors, over and above these historical developments, that have led investors to become unwilling to experiment with renewable energy production technologies. In this section, we outline these structural factors that VCs seem to be facing, making sustained funding of entrepreneurship in renewable energy difficult.

\subsubsection{Capital Intensity and Time Frame of Energy Production}

Two facts about VC investments make staging very attractive. First, the ex post distributions of VC returns tend to be extremely skewed. Hall and Woodward (2010) and Sahlman $(1990,2010)$ document that about 60 percent of VC investments are likely to go bankrupt and the vast majority of returns are typically generated from about 10 percent of the investments that do extremely well. Second, Kerr, Nanda, and Rhodes-Kropf (2014) document how hard it is for VCs to predict which start-ups are likely to be extremely successful 
and which will fail at the time of first investment. The VCs therefore invest in stages, in effect buying a series of real options, where the information gained from an initial investment either justifies further financing or the exercise of the VC's abandonment option to shut down the investment (Gompers 1995; Bergemann and Hege 2005; Bergemann, Hege, and Peng 2008; Guler 2007). This helps them to invest as little as possible in start-ups that end up failing and put a larger share of their money in start-ups that ultimately succeed.

Hence, properties of start-ups that maximize the option value of their investments make their portfolio more valuable. For example, investments that are capital efficient (cost of buying the option is less), where step ups in value when positive information is revealed are large relative to the investment (more discriminating "experiments" being run with the money that is invested), and where the information about the viability of a project is revealed in a short period of time are all properties that make investments more attractive for VCs.

Sectors such as IT and software, that have relatively low levels of capital investment, and where initial uncertainty about the viability of the technology is revealed quickly, are therefore ideal sectors for VCs. On the other hand, the unit economics of energy production technologies need to be demonstrated at scale, because even if they work in a lab, it is hard to predict how they will work at scale. This implies that demonstration and first commercial plants face technology (in addition to engineering) risk and hence are too risky to be financed through debt finance. The fact that "risk capital" is required even at the later stages of a renewable energy start-up implies that VCs who back such start-ups therefore need to finance the companies through extremely long and capital intensive investments. The resolution of uncertainty takes much longer, as start-ups often need to build demonstration and first commercial plants before it is clear that the technology is truly viable.

The funds required to prove commercial viability for energy production technologies can reach several hundred million dollars over a five- to tenyear period, compared to the tens of millions that VCs are typically used to investing in any given start-up. ${ }^{13}$ This level of investment is not feasible from a typical venture capital fund without severely compromising the diversification of the venture firm's portfolio. For example, investing only eight to fifteen million dollars in a project that is twice as capital intensive halves the dollar return if the start-up is successful (or it requires that the start-up to be twice as valuable at exit. This is typically not the case, as elaborated on below). On the other hand, investing a sufficient amount to retain a large share in a successful exit requires making far fewer investments across the portfolio and hence

13. For example, Solyndra, a company that manufactured photovoltaic systems using thinfilm technology, raised $\$ 970$ million in equity finance in addition to a $\$ 535$ million loan guarantee from the Department of Energy, prior to its planned IPO in mid-2010. This amount of capital to prove commercial viability is an order of magnitude greater than the $\$ 40-\$ 50$ million that VCs are typically used to investing in each company to get them to a successful exit. 


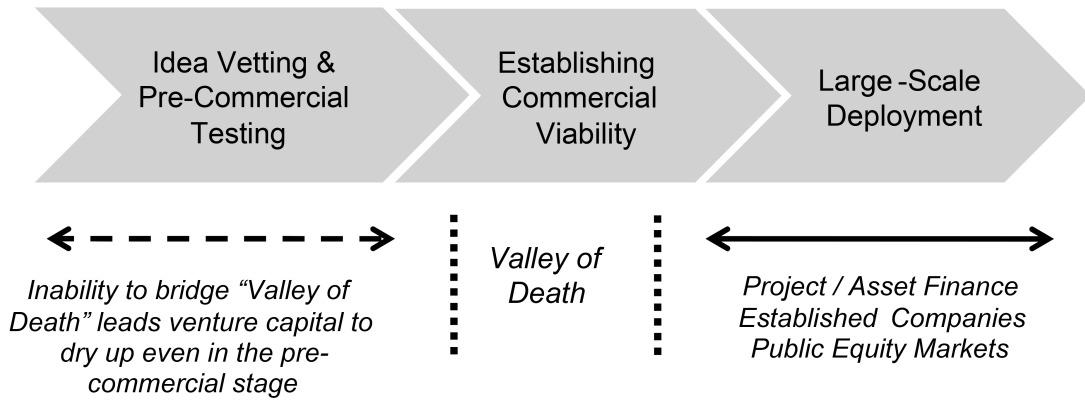

Fig. 7.6 Funding gaps and the "valley of death"

Source: Ghosh and Nanda (2014).

makes the portfolio much more risky. Such investments are thus typically too capital intensive for VCs, given the size and structures of most VC funds today.

The inability to raise either debt or venture capital at the demonstration and first commercial stage has led this stage of the start-up's life to be known as the "valley of death" (see figure 7.6). The fact that investors are now acutely aware of this funding gap before the firm gets to cash flow positive leads to an unraveling of the entire financing chain. That is, since investors forecast that even promising start-ups may have a hard time getting financing when they reach the stage of needing to build a demonstration plant, the benefits of sinking capital in a start-up at the stage before may not be worthwhile. This logic, that VCs refer to as financing risk, works through backward induction to the first investor. Thus, a forecast of limited future funding may lead promising projects to not be funded, even if when fully funded, they would be viable and NPV positive investments (e.g., see Nanda and Rhodes-Kropf 2012).

\subsubsection{Exit Opportunities and Financing Risk}

The VCs do invest in some industries such as biotechnology, semiconductors, and IT/networks that also share the attributes of huge financing requirements that are outside the scope of a start-up. However, in these instances, VCs bank on an established exit mechanism to hand over their early stage investments before they hit the valleys of death. For example, in the biotechnology industry, the VC model evolved over fifteen to twenty years in such a way that pharmaceutical companies stepped in to buy promising start-ups at a point even before commercial viability had been proven. This is a key part of the innovation ecosystem as it bridges the potential valley of death and thereby facilitates precommercial VC investments in biotechnology. The propensity of pharmaceutical companies to buy promising start-ups also facilitates their initial public offerings (IPOs) at precommercial stages, because public investors believe there is sufficient competition among pharmaceutical firms for biotechnology start-ups with innovative solutions and that they 
will be acquired well before they hit the valley of death. Cisco, Lucent, HP, and Juniper networks play an equivalent role in the IT/networking industry.

Thus far, however, energy-producing firms and utilities that supply electricity to customers have been far from active in acquiring promising clean energy start-ups. This bottleneck in the scaling-up process has a knock-on effect on the ability for VCs to fund precommercial technologies in this space as well. If early stage venture investors face the risk that they may be unable to raise follow-on funding or to achieve an exit, even for start-ups with otherwise good (but as yet unproven) technologies, they run the danger of sinking increasing amounts of dollars for longer periods of time to keep the start-up alive. With incumbent firms unwilling to buy these start-ups at precommercial stages, the time to exit for the typical start-up is much longer than the three- to five-year horizon that VCs typically target (the time to build power plants and factories is inherently longer than a software sales cycle and can even take longer than the life of a VC fund). Moreover, each time the start-up needs to return to the capital market for ever larger amounts of financing makes them vulnerable to the state of the capital markets for an extended period of time. As shown in figure 7.6, this leads venture capitalists to withdraw from sectors where they could have helped with the precommercial funding, but where they are not certain that they will be able to either fund the project through the first commercial plant, or they are not sure if they can exit their investment at that stage (Nanda and Rhodes-Kropf 2013). In fact, the history of capitalintensive industries such as biotechnology, communications networking, and semiconductors suggests that until the incumbents start buying start-ups, the innovation pipeline does not truly take off.

The biotechnology industry took several years to develop a financing ecosystem that allowed VCs to back start-ups and large companies to buy and scale them. Indeed, average $\mathrm{VC}$ returns to biotech investments are low, and even today the challenges associated with this model have led most VCs to exit this sector, leaving only a few specialist investors to focus on the industry and leading others to propose new funding models to drive innovation in drug development (Fernandez, Stein, and Lo 2012).

While in some ways, the renewable energy industry resembles the early days of the biotech industry (thereby giving hope that the ecosystem will develop in time), there are reasons to believe that achieving the same ecosystem may be harder in renewable energy. In the case of the biotechnology industry, a clear exit mechanism was facilitated by a vibrant market for ideas (Gans, Hsu, and Stern 2002) and the fact that the US Food and Drug Administration (FDA) developed well-understood and transparent metrics for success at each stage. Because the set of buyers was uniform and the criteria for a successful exit at each stage had been developed and well understood, VCs could work backward and set their own investment milestones. In this way, the downstream exit process had important consequences for the direction of upstream innovation. The extent to which large energy compa- 
nies will play an equivalent role in the innovation pipeline for clean energy is not yet clear. There are some signs that this may be changing, with the most promising developments being the rise of a number of corporate venture capital funds among the large energy companies (Nanda and Rothenberg 2011) as well as the growth of some extremely large and dedicated venture capital investors focused on the renewable energy sector.

\subsubsection{Global Commodities and Policy Risk}

A final important difference between the renewable energy production and the typical VC-backed start-up is that energy is a commodity. Success in energy comes from being a low-cost provider rather than having an innovation that can be priced high due to the willingness of end users to pay (as is the case for biotechnology). While incumbents in other industries compete with each other to acquire start-ups in order to meet end-user demand, the enduser in the energy market cannot distinguish electrons produced from coal, the sun, or the wind, unless the government prices the cost of carbon appropriately. In the absence of appropriate price signals or incentives to invest in renewables, incumbents are therefore not pressed to acquire start-ups in this space. In the case of biofuels, the inputs to their production process are also commodities. Energy producers therefore face commodity risk for both raw materials and end products. Since these markets can exhibit substantial price volatility, it makes running and managing these companies more difficult. For example, second- and third-generation biofuel start-ups producing ethanol or biocrude at $\$ 80-\$ 90$ per barrel were competitive in 2007 prior to the global recession when conventional oil prices topped $\$ 100$ a barrel, but most went bust when oil prices plummeted in the subsequent recession.

The challenges of backing a global commodity producer are compounded by the fact that energy and clean energy are sectors with large involvement by governments across the world. Given that clean energy technologies have not yet achieved grid parity, government policy is also critical in determining the prices of inputs and finished products. Some governments choose to either tax carbon content in conventional fuels or to buy clean energy at a premium. Others choose to subsidize clean energy companies through direct grants and subsidies or through tax breaks. Regardless of the policy, it implies that the extent to which a given start-up's product is likely to be profitable depends greatly on whether it is included in the subsidy or credit, the extent to which carbon is taxed, or the price premium at which the government buys the commodity.

Policy changes and uncertainty are thus major factors hindering the potential investment by private sector players across the clean energy investment landscape (Bloom 2009). This is particularly true when the periodicity of the regulatory cycle is smaller than the investment cycle required for demonstrating commercial viability. In such an event, no one is willing to invest in the first commercial plant if they do not know what the regulatory environment is going to be by the time success has been demonstrated (based on the rules of the prior regulatory regime). 


\subsection{Conclusion}

Innovation in renewable energy has grown in recent years, in part due to the sharp rise in venture capital finance for renewable energy start-ups in the early years of the twenty-first century. However, the availability of venture capital finance for renewable energy has fallen dramatically in recent years. In this chapter, we ask whether we should worry that the decline and shift in VC will slow the rate and alter the direction of innovation in renewable energy.

Our results suggest that start-ups backed by venture capital file patents that are more likely to have at least one citation are more likely to be highly cited, have fewer self-citations, and are more likely to be novel than patents filed by incumbent firms. Although the lag in the patent grants do not allow us to directly observe how the falling levels of $\mathrm{VC}$ finance relate to the innovations by VC-backed start-ups, our results suggest VC financing is associated with a greater degree of economic experimentation and therefore, their shift away from financing renewable energy start-ups could impact the rate and trajectory of innovation in these industries.

Our chapter has also aimed to shed light on some of the structural factors that have made sustained experimentation by VCs hard, with a particular emphasis on the difficulty of exiting their investments to incumbent firms that have the expertise and capital to finance the scale up of such technologies. Larger/longer funds may be one alternative, since such funds could get past the uncertainty and to a stable place for exit, but measures designed to incentivize incumbents up the financing chain to bridge the valley of death also seem like possible solutions.

Although the US government has played a role in supporting clean technology innovation in the United States, the vast majority of this has been on the "supply side," through the direct support of individual firms (Roberts, Lassiter, and Nanda 2010). In addition to policies that would put a price on carbon, our discussion suggests that facilitating a more vibrant exit environment for start-ups at precommercial stages has the potential to stimulate greater private-sector funding of these start-ups, thereby increasing the degree of innovation and entrepreneurship in renewable energy.

We should note that our analysis is not meant to suggest that the innovations undertaken by incumbent firms are unimportant, or that the focus of VC on other aspects of clean tech is not valuable. Rather, our objective is to highlight the fact that the shifting focus of venture capital is likely to have an impact on both the rate and the characteristics of renewable energy innovation in the coming years. To the extent that there is still a need for experimentation with new technologies and a desire to commercialize radical innovations in renewable energy, our work highlights that there are structural factors that make sustained experimentation by VCs difficult in renewable energy. Although it is still early in the life cycle of this industry, our discussion has outlined some specific factors that may facilitate the deployment of large amounts of risk capital that are necessary to finance renewable energy innovations. 


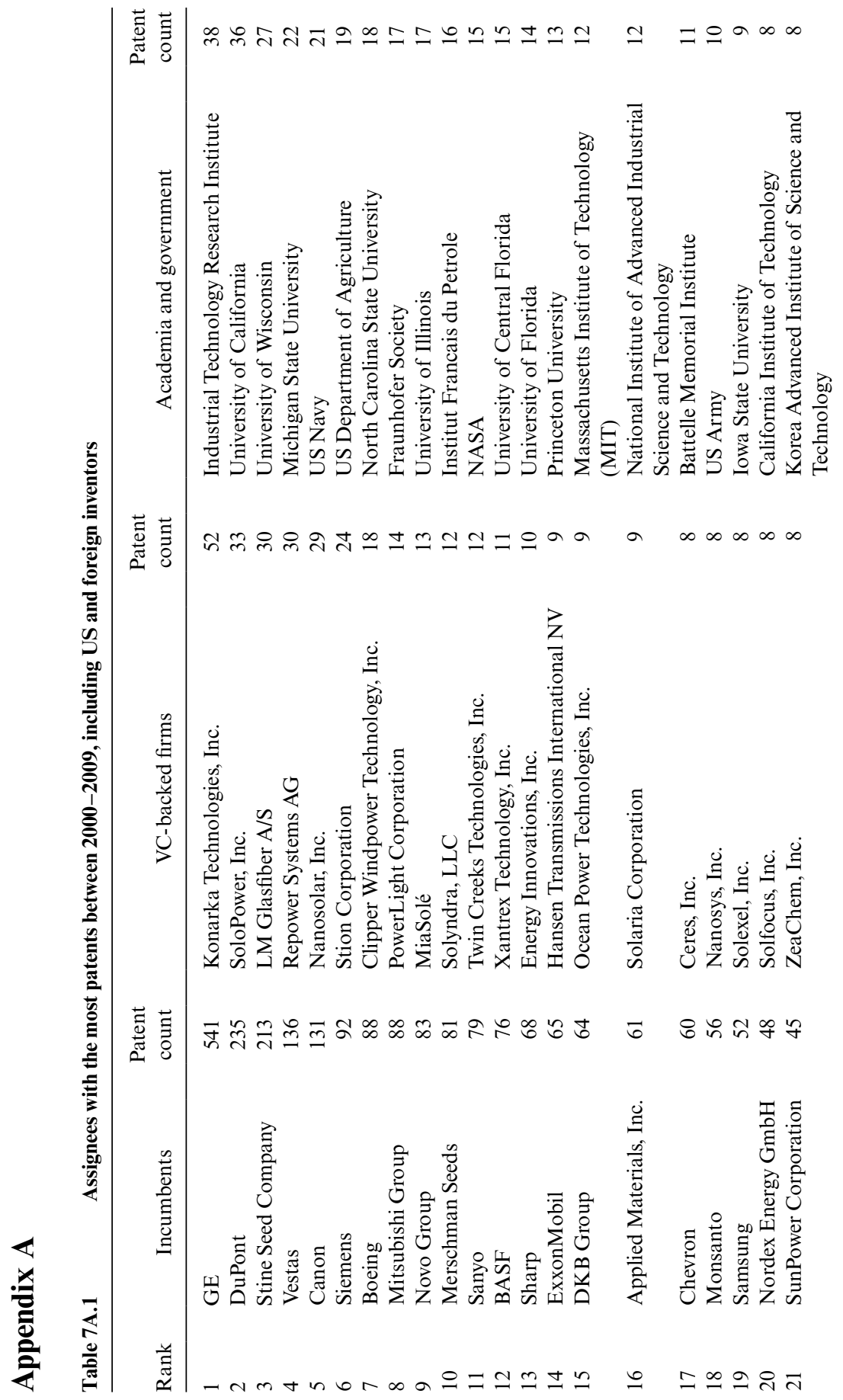



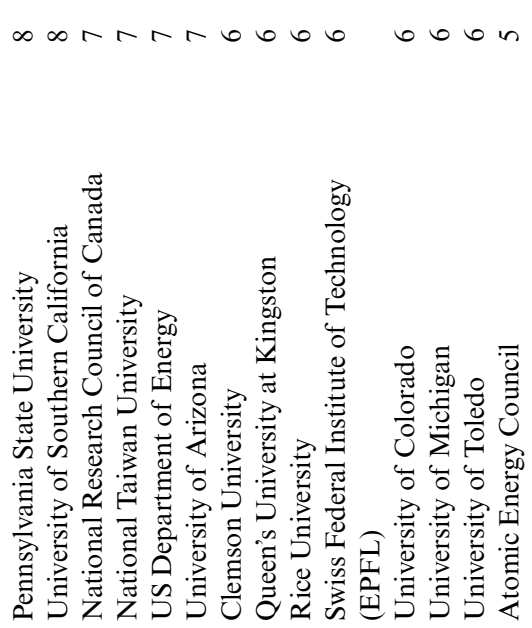

N-NG66 on in in in in

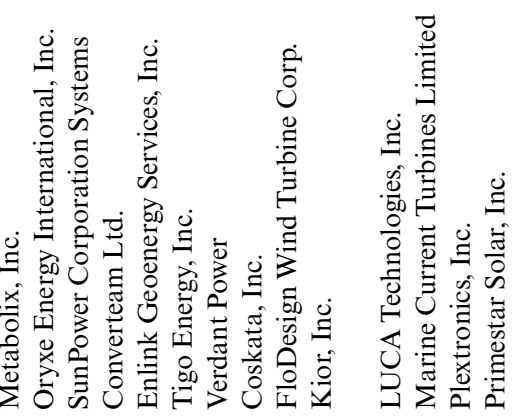

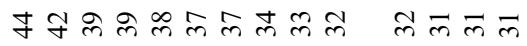

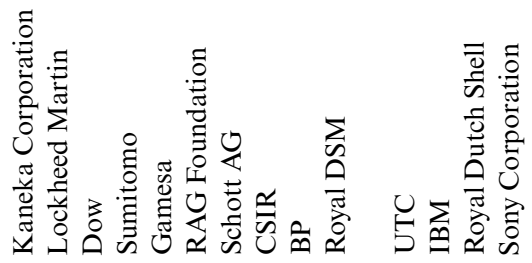

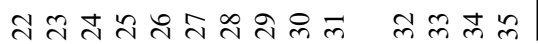




\section{Appendix B}

\section{New Measure of Novelty}

We have developed a new measure of novelty that is not based on citation measures. Instead, we draw on a textual analysis of patent applications to look at the similarity of patent claims and descriptions for patents in a given technology area. Intuitively, our definition is such that patents with greater textual similarity to neighboring patents are considered to be less novel. Our measure of novelty should be particularly useful in the context of science-based patenting, where technical terms are more unique and therefore more likely to signal differences in the characteristics of innovation, and for more recent time periods, where initial forward citations may be a noisy predictor of ultimate outcomes. The general outline for the calculation of the measure is as follows: First, the calculation algorithm reviews every patent claim and description in the sample to build a list of all terms used; the list of terms constitutes a highdimensional positive space wherein each term represents a dimension into that space. Second, the algorithm positions each patent in the vector space by assigning it a set of coordinates where the magnitude of each dimension is calculated as the "term frequency inverse document frequency" (TF-IDF) of each term in the patent. Intuitively, TF-IDF gives a greater weight to a dimension when a term occurs more frequently in the patent, and gives a lesser weight to a dimension if the word is frequently observed in other patents as well. Third, the algorithm calculates the "similarity" between every possible combination of two patents, by calculating the cosine of the angle formed between their vectors. The measurement of similarity is bounded $[0,1]$, with a measurement of 1 representing a perfect similarity between two patents.

Having thus arrived at a pair-wise list of similarity comparisons between every possible combination of patents in the sample, the algorithm then calculates a measurement of novelty for each focal patent by examining the distribution of similarities relative to a comparison set of patents. The comparison set is drawn from the prior three years and from the same technology area as the focal patent (e.g., "solar"). To assess the novelty of a patent - a concept connoting few neighbors in the technology landscape - we take the 5 th percentile of the rank-ordered distribution of similarities tied to the comparison set. For ease of interpretation, we reverse the novelty measure by subtracting it from 1, arriving at a measurement for novelty that is bounded [0,1], where 1 represents a patent that is entirely dissimilar from all other patents. When needed, we average patent-level measures of novelty up to the firm or category level. 


\section{References}

Akcigit, Ufuk, and William Kerr. 2011. "Growth through Heterogeneous Innovations." Working Paper, Harvard Business School, Harvard University.

Bergemann, Dirk, and Ulrich Hege. 2005. "The Financing of Innovation: Learning and Stopping." RAND Journal of Economics 36:719-52.

Bergemann, Dirk, Ulrich Hege, and Liang Peng. 2008. "Venture Capital and Sequential Investments." Cowles Foundation Discussion Paper no. 1682, Cowles Foundation for Research in Economics.

Bloom, Nicholas. 2009. "The Impact of Uncertainty Shocks.” Econometrica 77: 623-85.

Bloomberg New Energy Finance. 2010. "Crossing the Valley of Death: Solutions to the Next Generation Clean Energy Project Financing Gap." White Papers, June. http://about.bnef.com/white-papers/crossing-the-valley-of-death-solutions-tothe-next-generation-clean-energy-project-financing-gap/.

BP. 2012. Statistical Review of World Energy. http://www.bp.com/content/dam/bp/ pdf/Statistical-Review-2012/statistical_review_of_world_energy_2012.pdf.

Conti, Annamaria, Jerry Thursby, and Marie Thursby. 2013. "Patents as Signals for Startup Financing?” Journal of Industrial Economics 22 (2): 592-622.

Fan, Rong-En, Kai-Wei Chang, Cho-Jui Hsieh, Xiang-Rui Wang, and Chih-Jen Lin. 2008. "LIBLINEAR: A Library for Large Linear Classification." Journal of Machine Learning Research 9:1871-74.

Fernandez, Jose-Maria, Roger M. Stein, and Andrew W. Lo. 2012. "Commercializing Biomedical Research through Securitization Techniques.” Nature Biotechnology 30:964-75.

Gans, Joshua, David Hsu, and Scott Stern. 2002. "When Does Start-Up Innovation Spur the Gale of Creative Destruction?" RAND Journal of Economics 33:571-86.

Ghosh, Shikhar, and Ramana Nanda. 2014. "Venture Capital Investment in the Clean Energy Sector." Harvard Business School Entrepreneurial Management Working Paper no. 11-020, Harvard University.

Gompers, Paul. 1995. "Optimal Investment, Monitoring, and the Staging of Venture Capital." Journal of Finance 50:1461-89.

Gompers, Paul, and Josh Lerner. 2002. The Venture Capital Cycle. Cambridge, MA: MIT Press.

Guler, Isin. 2007. "Throwing Good Money after Bad? A Multi-Level Study of Sequential Decision Making in the Venture Capital Industry." Administrative Science Quarterly 52:248-85.

Hall, Robert, and Susan Woodward. 2010. "The Burden of the Nondiversifiable Risk of Entrepreneurship.” American Economic Review 100 (3): 1163-94.

Henderson, Rebecca, and Kim Clark. 1990. "Architectural Innovation-The Reconfiguration of Existing Product Technologies and the Failure of Established Firms." Administrative Science Quarterly 35 (1): 9-30.

Kerr, William, Ramana Nanda, and Matthew Rhodes-Kropf. 2014. "Entrepreneurship as Experimentation." Journal of Economic Perspectives 3:25-48.

Kortum, Samuel, and Josh Lerner. 2000. "Assessing the Contribution of Venture Capital to Innovation." RAND Journal of Economics 31 (4): 674-92.

March, James. 1991. "Exploration and Exploitation in Organizational Learning." Organizational Science 2:71-87.

Nanda, Ramana, and Matthew Rhodes-Kropf. 2012. "Financing Risk and Innovation.” Harvard Business School Working Paper no. 11-013, Harvard University. 
2013. "Investment Cycles and Startup Innovation." Journal of Financial Economics 110(2): 403-18.

Nanda, Ramana, and Juliet Rothenberg. 2011. "A Quiet Revolution in Clean Energy Finance.” Harvard Business Review (blog). http://blogs.hbr.org/2011/10/quiet -revolution-clean-energy-finance/.

Popp, David, Ivan Hascic, and Neelakshi Medhi. 2011. "Technology and the Diffusion of Renewable Energy.” Energy Economics 33:648-62.

Roberts, Michael, Joseph Lassiter, and Ramana Nanda. 2010. "US Department of Energy \& Recovery Act Funding: Bridging the 'Valley of Death'." Harvard Business School Case 810-144, Harvard University.

Rosenberg, Nathan. 1994. "Economic Experiments." In Inside the Black Box, edited by Nathan Rosenberg. Cambridge: Cambridge University Press.

Rosenkopf, Lori, and Atul Nerkar. 2001. "Beyond Local Search: Boundary-Spanning, Exploration, and Impact in the Optical Disk Industry." Strategic Management Journal 22(4): 287-306.

Sahlman, W. 1990. "The Structure and Governance of Venture-Capital Organizations." Journal of Financial Economics 27:473-521.

—. 2010. "Risk and Reward in Venture Capital." Harvard Business School Background Note no. 811-036, Harvard University.

Samila, Sampsa, and Olav Sorenson. 2011. "Venture Capital, Entrepreneurship and Economic Growth." Review of Economics and Statistics 93:338-49.

Singh, Jasjit, and Lee Fleming. 2010. "Lone Inventors as Sources of Breakthroughs: Myth or Reality?" Management Science 56 (1): 41-56.

Sorensen, Jesper, and Toby E. Stuart. 2000. "Aging, Obsolescence and Organizational Innovation." Administrative Science Quarterly 45:81-112.

Stern, Scott. 2005. "Economic Experiments: The Role of Entrepreneurship in Economic Prosperity." In Understanding Entrepreneurship: A Research and Policy Report, edited by Carl J. Schramm. Kansas City, MO: Ewing Marion Kauffman Foundation.

Tripsas, Mary, and Giovanni Gavetti. 2000. "Capabilities, Cognition and Inertia: Evidence from Digital Imaging.” Strategic Management Journal 21:1147-61.

Tushman, Michael L., and Philip Anderson. 1986. "Technological Discontinuities and Organizational Environments." Administrative Science Quarterly 31 (3): 439-65.

Ullman, Jeff, and Anand Rajaraman. 2011. Mining of Massive Datasets. New York: Cambridge University Press. 